VOL. 6

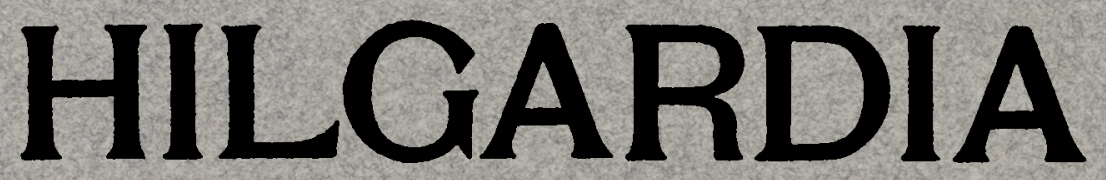

A Journal of Agricultural Science PUBLISHED BY THE

California Agricultural Experiment Station

CONTENTS

Factors Affecting California Raisin Sales and Prices, $1922-1929$

S. W. SHEAR and R. M. HOWE

Factors Affecting Annual Prices of California Fresh Grapes, 1921-1929

L. D. MALLORY, S. R. SMITH, and S. W. SHEAR 
The titles of the Tochnical Papers of the Oallfornis Agricultural Experimont Btation, Nos. 1 to 20, which HLCAARDIA replaces, and coples of which may be had on application to the Publication secretary, Agricultural Experiment Btation, Berkeley, are as follows:

4. Effect of Sodium Chlorid and Calcium Chlorid upon the Growth and Composition of Young Orange Trees, by H. 8. Roed and A. B. C. Haas. Apri1, 1923.

5. Oitrus Blast and Black P1t, by H. 8. Fawcett, W. T. Horne, and A. F. Camp. May, 1023.

6. A Btudy of Decidnous Frutt Tree Bootstocks with 8pecial Reference to Their Identiflcation, by Myer J. Heppner. June, 1923.

7. A Btudy of the Darkening of Apple Tlssue, by E. L. Overholser and W. V. Cruess. Juno, 1923.

8. Effect of Salts on the Intake of Inorganic Elements and on the Bufer System of the Plant, by D. R. Hoagland and J. O. Martin. July, 1928.

9. Experiments on the Reclamation of Alkall Solls by Leaching with Water and Gypsum, by P. L. Fubbard. August, 1923.

10. The Beasonal Varlation of the Boil Molsture in a Walnat Grove in Relation to Hygroscopic Coefficient, by I. D. Batchelor and II. 8. Reed. Beptember, 1923.

11. Btudies on the Effects of sodium, Potassium, and Calclum on Young Orange Trees, by H. 8. Roed and A. R. O. Haas. October, 1923.

12. The Effect of the Plant on the Beaction of the Oulture Solution, by D. $R$. Hoagland. November, 1923.

14. The Respiration of Potsto Tubers in Rolation to the Occurrence of Blackheart, by J. P. Bennett and E. T. Bartholomew. January, 1924.

16. The Molsture Equivalent as Infuenced by the Amoant of Boll Used in its Determination, by F. J. Veinmeyer, O. W. Isrzalsen and J. P. Conrad. September, 1924

17. Nutrient and Toxdc Effects of Certain Ions on Otrus and Walnut Trees with Especial Reference to the Concentration and Ph of the Medium, by H. 8. Reed and A. R. O. Haas. October, 1924.

18. Factors Infuencing the Rate of Cfermination of Seed of Asparagus Oflednalis, by EL \& Borthwick March, 1925.

10. The Relation of the Bubcutaneous Administration of Idifing Bacterine sbortum to the Immunity and Carrier Problem of Bovine Infectlous Abortion, by George H. Hart and Jacob Traum. April, 1925.

20. A study of the Conductive Tissues in Bhoots of the Bartlett Pear and the Relationship of Food Movement to Dominance of the Apical Buds, by Frank E. Ctardner. April, 1925. 


\section{FACTORS AFFECTING ANNUAL PRICES OF CALIFORNIA FRESH GRAPES, 1921-1929'}

L. D. MALLORY2, S. R. SMITH ${ }^{3}$, AND S. W. SHEAR4

This paper presents the results of an analysis designed to discover and measure the influence of the major factors that have affected the season's price of each class of California fresh grapes-table, black-juice, and white-juice.

The total quantity of California grapes produced in any one year is determined by the bearing acreage, the environmental conditions of growth in that year, and the care expended in their culture. During any one harvesting season, therefore, the total available supply of grapes is not subject to great change. Because the supply of fresh grapes for any given season is relatively fixed it is primarily pricedetermining rather than price-determined. However, the two-way usage of raisin grapes has some effect upon the quantity of that class of grapes marketed fresh. Raisins take a large portion of the crop, and the relative profitableness of shipping fresh or of drying into raisins influences the amounts utilized in one way or the other. The two uses, however, tend toward equality of returns. With a relatively fixed supply for any given year, changes in price other than those accounted for by year-to-year changes in fresh shipments, therefore, are the result of factors influencing demand. Because of this fact, a large part of this study is devoted to factors which have influenced the demand for fresh grapes. ${ }^{5}$

1 Paper No. 21, The Giannini Foundation of Agricultural Economics. This study was made with the financial cooperation of the Federal Farm Board.

2 Research Assistant in Agricultural Economics.

3 Temporary Research Assistant in the Federal Farm Board.

4 Associate Agricultural Economist in the Experiment Station and Associate Agricultural Economist on the Giannini Foundation.

5 An excellent discussion of the relation of statistical analysis to the laws of price will be found in: Ezekiel, Mordecai. Statistical analysis and the 'laws' of price. Quar. Jour. of Econ. 42:199-227. Feb. 1928.

Some discussion of factors affecting California grape prices will be found in the following: Shear, S. W., and H. F. Gould. Economic status of the grape industry. California Agr. Exp. Sta. Bul. 429:81-94. 1927. (Continued on page 102) 
Were the schedule of demand for California grapes to remain the same over a period of years, it would be possible from data on annual prices and shipments to construct a schedule of prices at which different numbers of carloads could be sold. Explanation of prices and forecasting of season's average prices from shipments would thus be made easy. However, the problem is far from being simple because the demand for the various classes of grapes changes from year to year.

\section{DATA USED}

It was necessary to base this analysis on data covering a period of only nine years. Data for years previous to 1921 are limited both as to scope and accuracy. Moreover, the effects of the very abnormal influences of the World War upon prices and other economic conditions for the years just previous to 1921 made the inclusion of data for earlier years inadvisable.

Even as it is, the rapid changes that have occurred in the California grape industry since 1920 have introduced.decisive trends and other changes into the data, the effects of which have seriously complicated the analysis. Grape prices, along with other fruit prices, remained high for a year or two longer than the price of staple farm products immediately after the War. Eastern demand for juice grapes was also stimulated by prohibition. Largely as a result of these two facts, grape plantings increased rapidly in California for several years after 1921, with the consequence that production and shipments have followed a rapid upward trend accompanied by drastic declines in the price of all classes of grapes.

Because the greater part of California fresh grapes has been consumed in eastern cities, prices accurately representing actual sales in these markets were desired. For this reason, farm prices were not used nor, chiefly for the same reason, were f.o.b. prices. Moreover, for the years included in the analysis, f.o.b. prices were not quoted

Stover, H. J. Relation of the production of grapes in western New York and in California to prices. N. Y. S. College Agr., Cornell Univ., Farm Economics No. 59, p. 1111-1113. June, 1929.

Stover concludes that "The multiple correlation between (annual data 19101926 on) the purchasing power of the price (i.e. adjusted price) of table grapes in California $\left(\mathrm{X}_{1}\right)$, the production of grapes in western New York $\left(\mathrm{X}_{2}\right)$, and the production of table grapes in California $\left(X_{3}\right): R_{1.23}=0.768 \pm 0.067$, indicates that the production of grapes in the two areas accounts for 59 per cent of the factors determining the price received in California. Of this amount, 10 per cent is due to western New York production and 49 per cent to California production. (Note that relatively few California table grapes were unharvested before 1927.) 
with sufficient regularity to constitute complete series, their manner of collection was not sufficiently accurate, and the quantities sold at the various prices were not available.

An accurate measure of price could have been obtained from the sales on the eleven auction markets. ${ }^{6}$ Comparison showed, however, that New York delivered-auction prices and the average for the eleven delivered-auction markets differed relatively little. The New York market area receives approximately 20 per cent of the interstate movement of California grapes. Moreover, it is in the same diversion zone as Boston, Baltimore, Pittsburgh, and Philadelphia. Hence, New York auction prices were chosen as representative of eastern sales. Using prices for this one market also obviated the necessity of taking into account varying lengths of time required for transportation from California to different markets when studying the movement of prices during a season, making possible the use of uniform lags between time of shipment and prices upon arrival.

As a measure of the annual quantities of each class of California fresh grapes bought at prices equivalent to the annual New York delivered-auction prices, annual rail shipments (inter and intrastate) of each class of grapes were used. Local truck movement and some small additional tonnage consumed in California is, of course, excluded from rail movement, but the total is relatively small, is difficult to estimate accurately, and probably has influenced eastern prices but little, if at all.

About the only other part of California grape production excluded from rail shipments that may have influenced eastern prices of fresh grapes has been the quantities left unharvested in a number of recent years and the tonnage of raisin grapes that might be diverted from drying to swell the fresh movement. Although the unharvested tonnage may have had some influence psychologically in depressing eastern prices, largely because of the uncertainty of whether some of it might be shipped, the effect has apparently been too small to be appreciable or else has been obscured by other factors. The option of raisingrape growers of drying or of shipping their grapes fresh has had an appreciable bearing upon fresh Muscat shipments, as discussed later, but has been exercised but little in the case of Thompson Seedless and Sultana.

An added advantage of using data on rail shipments is that they provide comparable supply data as a basis for studying seasonal

6. Baltimore, Boston, Chicago, Cincinnati, Cleveland, Detroit, Minneapolis, New York, Philadelphia, Pittsburgh, St. Louis. 
variation in prices. Additional data used on current movement were arrivals, track holdings, and unloads. Data on unloads, however, were unavailable for 1925 and 1926, and hence the volume of deliveredauction sales was substituted as a measure of current rate of movement into consumption.

\section{TABLE GRAPES}

As shown by figure 1, variations in the supply of California table grapes account for nearly all the year-to-year changes in adjusted seasonal average ${ }^{7}$ prices for the nine years 1921 through $1929 . .^{8}$ As California shipments have increased (fig. 1 and table 1), New York delivered-auction prices have declined, and vice versa. The regression line $d d^{\prime}$, fitted free-hand to the points of the scatter diagram, shows the close relation normally existing between prices and shipments and indicates about how much of a change in price might normally be expected from a given change in table-grape shipments. The demand indicated by this curve is somewhat inelastic. Hence the total value of grapes sold in eastern markets tends to be smaller when annual shipments are heavy than when they are light. With shipments of from about 25,000 to 31,000 carloads of table grapes, elasticity of demand varies from somewhat more than 0.8 with the lighter shipments and higher prices to somewhat less than 0.7 with the heavier shipments and lower prices. The demand appears to be most elastic when supplies are small and prices relatively high. ${ }^{9}$.

The regression line in figure 1 may be used to estimate the adjusted price at which any given number of carloads of California table grapes may be expected to sell during a marketing season. The

7 Variations in the general level of prices were relatively small during the period 1921-1929 and the variations in grape prices associated with them were too small to be important. However, the probability of future substantial changes in the general price level which might appreciably influence grape prices, led to the decision to adjust actual prices during the period studied. The Bureau of Labor Statistics all-commodity wholesale price index was used in making these adjustments.

8 This study was completed before adequate data on the marketing of the 1930 crop were available, and hence they have not been included in the present analysis. However, the preliminary data available show that tablegrape prices in 1930 were very closely in line with the regression curve in figure 1. About 26,800 carloads were shipped and the average New York delivered-auction price was about $\$ 95$ a ton actual or about $\$ 110$ adjusted.

9 For a comparison with the elasticity of other classes of California grapes see page 111 for black-juice, page 121 for fresh Muscats. The elasticity of domestic demand for raisins is given in the accompanying paper: Shear, S. W. and R. M. Howe, Factors affecting California raisin sales and prices, 19221929. Hilgardia 6:78. 1931. 
estimated adjusted price can then be converted to an estimated unadjusted price by multiplying by an estimate of the all-commodity wholesale price index for the current calendar year and pointing off two decimal places.

Obviously the relation shown in figure 1 is not perfect, for all the points in the scatter do not fall exactly upon the regression line. Other factors than shipments, therefore, have apparently affected eastern prices of California table grapes.

Relation of Shipments of Table Grapes to Adjusted New York Prices, 1921-1929

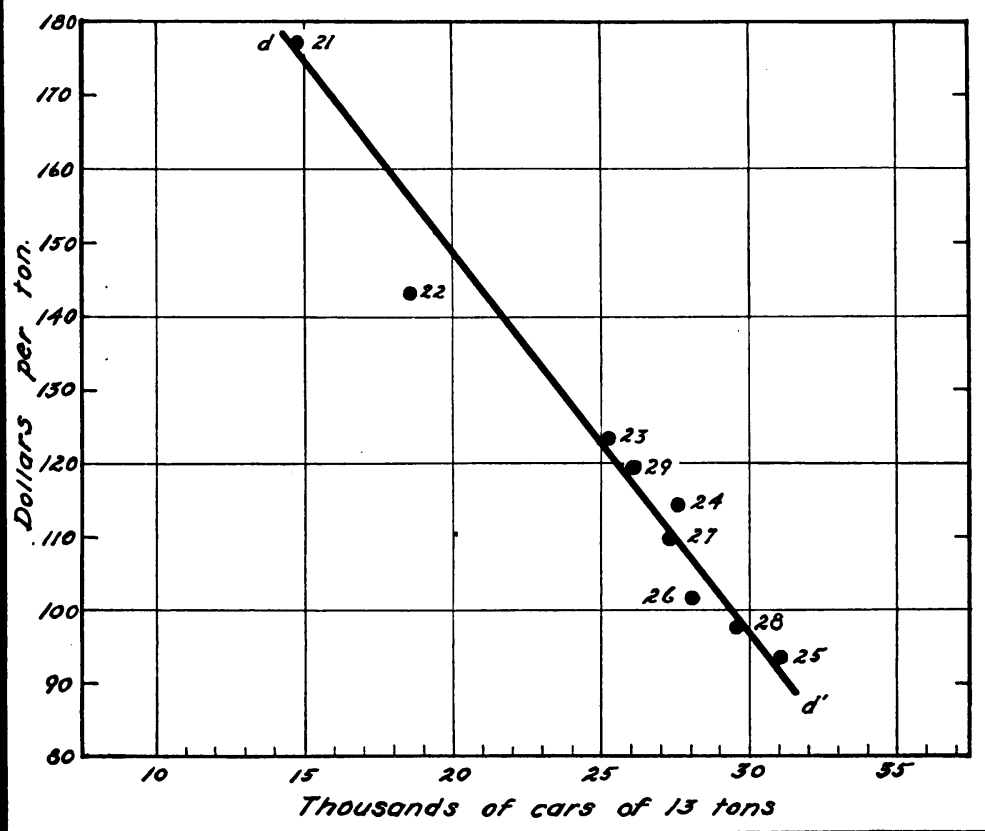

Fig. 1. Data from table 1.

Table grapes constitute on the average only some 30 per cent of the annual shipments of all California fresh grapes. The question, therefore, arises as to whether or not the supplies of other classes of grapes (black-juice and white-juice) have had an effect upon the price of table grapes. Superficially it seems that they would have had. However, although some Malaga and a few Tokay and Thompson Seedless have been sold as juice stock, analysis indicates that the small 
tonnage of fresh grape shipments having a two-way use has had little, if any, influence on the annual average price of California table grapes. The plotting of the deviations of price from the regression line in figure 1 against shipments of black-juice grapes and Muscats (severally, combined, and in conjunction with other factors) failed to show that these factors had a measurable influence. Apparently the price of table grapes has been little affected by changes in the proportion of total California shipments consisting of black-juice and white-juice grapes. Such a conclusion appears logical when an examination is made of the use of the different variety classes, of the marketing channels, and of the consumers of the different grapes.

\section{TABLE 1}

Annual Shipments and New York Delivered-Auction Prices of California Table Grapes, and Grape Shipments of Other. States, 1921-1929

\begin{tabular}{|c|c|c|c|c|}
\hline \multirow{3}{*}{ Crop year } & \multicolumn{2}{|c|}{ Shipments } & \multicolumn{2}{|c|}{ Price per ton } \\
\hline & California & Other states & Unadjusted & Adjusted \\
\hline & 1 & 2 & 3 & 4 \\
\hline & carloads & carloads & dollars & dollars \\
\hline $1921 \ldots$ & 14,800 & 4,473 & 172.80 & 177.05 \\
\hline 1922. & 18,600 & 15,967 & 138.40 & 143.12 \\
\hline $1923 \ldots$ & 25,240 & 9,988 & 124.00 & 123.26 \\
\hline $1924 \ldots \ldots$ & 27,600 & 12,238 & 112.00 & 114.17 \\
\hline 1925 & 31.100 & 5,812 & 96.80 & 93.53 \\
\hline 1926 & 28,100 & 14,732 & 101.60 & 101.60 \\
\hline $1927 \ldots \ldots \ldots$ & 27,300 & 6,752 & 104.80 & $109.85^{\circ}$ \\
\hline 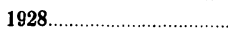 & 29,600 & 8,611 & 95.40 & 97.65 \\
\hline $1929 \ldots$ & 26,100 & 6,897 & 115.20 & 119.38 \\
\hline
\end{tabular}

Sources of data:

Col. 1: Total shipments, to the nearest hundred, both inter and intrastate, of all table-grape varieties-Malaga, Tokay, Emperor, Cornichon, and Almeria are the chief ones, and also of Thompson Seedless-in carloads of approximately 13 tons net of grapes. Data for 1928 and 1929 increased 6 per cent to allow for heavier loadings per car. Data for 1921-1926 from reference 1, $p$. 46. Note-Hereafter references used in sources of data will be numbered according to literature cited on pages 129 and 130). Data for 1927-1929 estimated by applying the variety percentages of interstate shipments to total California shipments including intrastate movement. Basic data for 1927 from reference 2, p. 10-12 and for 1928 and 1929 from references 3 and 4.

Col. 2: Carlot shipments from states other than California. Data for 1921-1923 from reference 5, p. 37-41; for 1924-1926 from reference 6, p. 138 and for 1927-1929 from U. S. Dept. Agr. mimeographed summaries, Monthly Carlot Shipments of Grapes.

Col. 3: Weighted average prices of New York delivered-auction sales of Tokay, Malaga, Cornichon, and Thompson Seedless varieties, in lugs and crates, through the first or second week of November. Converted to price per ton at the rate of 80 packages to the ton. Averages based on daily data as originally reported in the New York Fruit Reporter and summarized for 1924 in reference 12, p. 38-35: for 1925,1926 , and 1927 in reference $2, p .80-96$; for 1298 , in reference $9, p .47-94$; and for 1929 in reference 4.

Col. 4 : Prices adjusted to 1926 base by use of U. S. Dept. Labor Bureau of Labor Statistics allcommodity index of wholesale prices for calendar years. 
Table grapes ordinarily reach the ultimate consumer through retail stores, hotels, restaurants, etc., in very small lots for dessert purposes or for eating out of hand. Juice grapes, on the other hand, are seldom sold in lots of 5 or 10 pounds but reach the purchaser or consumer in lots of several lugs. This is because fairly large quantities are necessary for satisfactory results in the processing of a 'batch' of juice. A considerable portion of the juice grapes are sold in rather large quantities to people of foreign nativity, who, through custom or habit, demand a juice beverage for drinking purposes or as a part of their diet. This discrimination in consumptive uses of table grapes and of juice grapes probably largely accounts for the lack of price relation between the variety classes.

Unlike California juice grapes, the American type of slip-skin grapes of the labrusca species grown commercially in large quantities in eastern states is largely used for table consumption. Shipments of these grapes might, therefore, be expected to affect the demand for California table grapes in eastern markets. Plotting of the price residuals of figure 1 against total carlot shipments of grapes other than California (see table 1) indicates that shipments of eastern grapes have had some influence upon the price of California table grapes. In the scatter diagram, figure 1 , it will be seen that the points for the years 1922 and 1926 fall below the line, indicating a smaller average price than would have been expected from a normal relation. In each of these years shipments of eastern grapes were particularly large, being 15,967 carloads in 1922 and 14,732 carloads in 1926. However, the volume of eastern grape shipments apparently does not usually have much influence on the price of California table grapes. The two years noted are the only ones out of the nine in which a decided effect ean be observed. It was sufficiently important in those years, however, to warrant its being taken into account in any possible predictions.

There are some indications that the earliness or lateness of the bulk of market arrivals of eastern-grown grapes in relation to California arrivals may also affect the influence of season's total supplies of lubrusca grapes on California table-grape prices.

Because outstanding differences in the seasonal variation in shipments and prices might logically be expected to affect the relation of total season's shipments to season's average prices of California table grapes, such an analysis was made. The results were somewhat disappointing. In the analysis of average annual prices the relation between season's total shipments and average annual prices was marked, 
but the relation between weekly shipments and price provided results of only meager value in judging the course of prices from current supplies. It was found, however, that during seasons when shipments from California to eastern markets have assumed a fairly normal, orderly, and uniform movement, excluding periods in which there were abnormal factors such as a truckmen's strike, no major fluctuations have taken place. When shipments have moved East irregularly and large track holdings have accumulated in eastern markets, violent price fluctuations have usually taken place. The attempts of various California shipping organizations in recent years to avoid market gluts appear to have improved the seasonal movement of prices, thereby raising the average price for the season. The study of seasonal variations and fluctuations has emphasized the fact that current weekly prices in eastern markets are affected not only by current shipments but also, during the greater part of the shipping season, by total shipments expected during the whole season. This observation also applies to juice grapes.

The response of weekly prices to shipments during the four years 1926-1929 may be observed in figure 2. The year 1926 is a good example of great fluctuations in weekly prices due to irregular shipments. In contrast, during 1928 and 1929 shipments maintained a uniform flow and weekly prices were fairly uniform, with the exception of the portion of October, 1929, during which the truckmen's strike in New York City occurred.

Unfortunately, lack of appropriate data precluded statistical analysis of the influence of quality upon eastern prices of California table grapes, for there can be no doubt that quality has a substantial effect on prices. ${ }^{10}$ No accurate measure of the quality of grapes has been devised and the fragmentary information available is quite inadequate as a basis for statistical analysis. Attractive appearancewell-formed bunches of sound berries free from blemish-together with good flavor and high sugar content, are known to stimulate buying, while poor quality causes consumers to buy only at lower prices or else to turn to substitute fruits if available at attractive prices. Table grapes of poor quality are frequently sold for juice purposes at prices so low that they appreciably reduce the average annual price of table-grape varieties as a group.

\footnotetext{
10 According to a letter of June 11, 1930, from Mr. Earl R. French of the New York Food Marketing Research Council to the authors, a number of men in the fruit trade and in marketing research in New York City whom he interviewed expressed the opinion that next to quantity of the market supply, quality is perhaps the most important factor affecting California grape prices in eastern markets.
} 


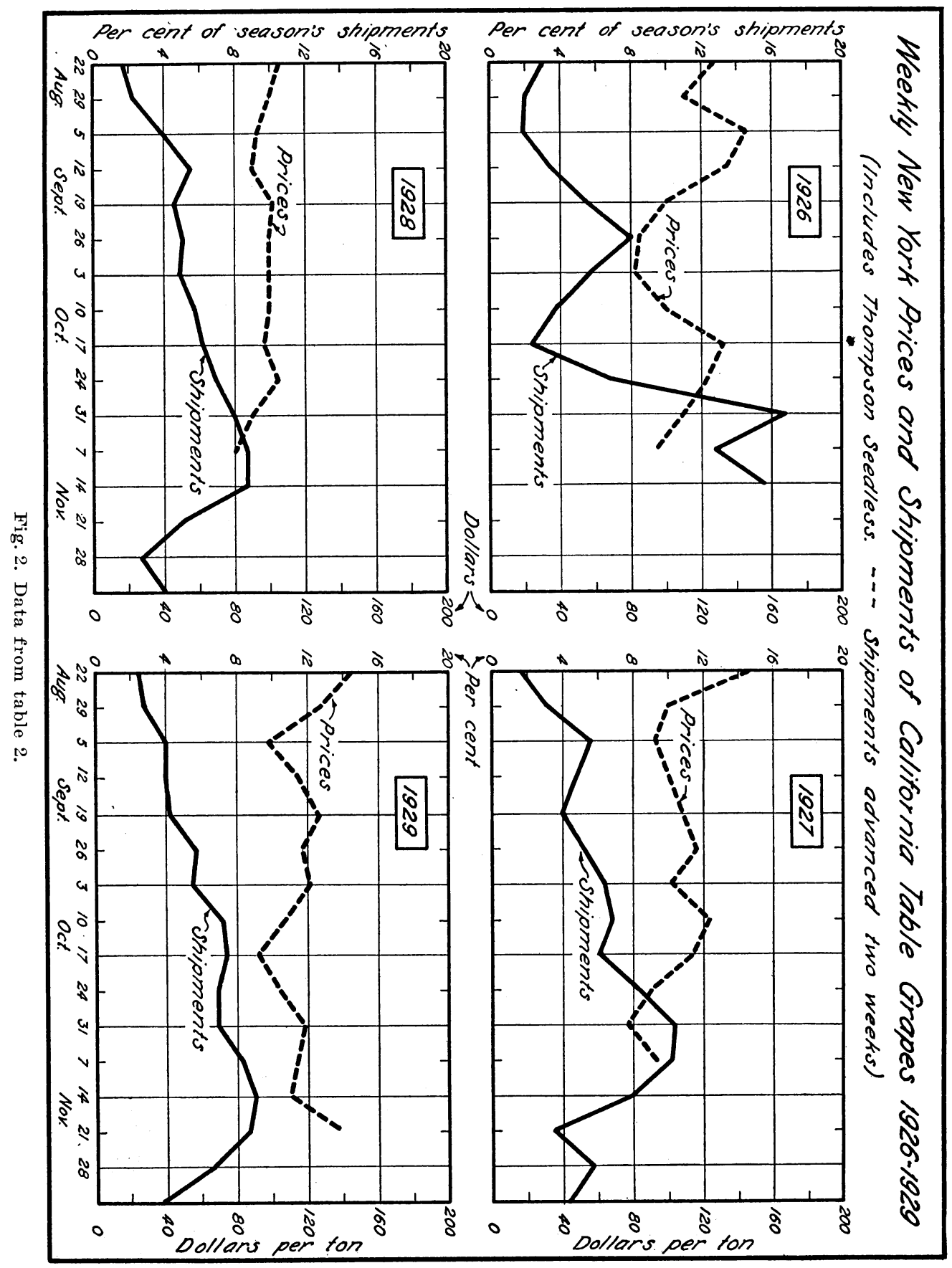




\section{TABLE 2}

Weekly New York Delivered-Auction Prices and Interstate Shipments in Carloads and in Per Cent of Season's Total, of

California Table Grapes, 1926-1929

\begin{tabular}{|c|c|c|c|c|c|c|}
\hline \multirow{3}{*}{$\begin{array}{l}\text { Week endings } \\
\text { (as of 1926) }\end{array}$} & \multirow{3}{*}{$\begin{array}{c}\begin{array}{c}\text { Price, } \\
\text { dollars } \\
\text { per ton }\end{array} \\
1\end{array}$} & \multicolumn{2}{|c|}{ Shipments } & \multirow[b]{2}{*}{$\begin{array}{c}\text { Price, } \\
\text { dollars } \\
\text { per ton }\end{array}$} & \multicolumn{2}{|c|}{ Shipments } \\
\hline & & Carloads & $\begin{array}{l}\text { Per cent of } \\
\text { season's } \\
\text { total }\end{array}$ & & Carloads & $\begin{array}{l}\text { Per cent of } \\
\text { season's } \\
\text { total }\end{array}$ \\
\hline & & 2 & 3 & 4 & 5 & 6 \\
\hline & \multicolumn{3}{|c|}{1926} & \multicolumn{3}{|c|}{1927} \\
\hline Season's total ......................... & $\ldots \ldots \ldots$ & $20.340 \dagger$ & $100.00 \dagger$ & $\ldots \ldots \ldots \ldots$ & $26,711 \dagger$ & $100.00 \dagger$ \\
\hline Aug. $\quad 7$........................ & 87.20 & 618 & 3.04 & 248.80 & 476 & 1.78 \\
\hline Aug. 14 & 119.20 & 404 & 1.99 & 166.40 & 821 & 3.07 \\
\hline Aug. 21.... & 129.60 & 390 & 1.92 & 147.20 & 1,486 & 5.56 \\
\hline Aug. $28 \ldots$ & 109.60 & 733 & 3.60 & 100.80 & 1,285 & 4.81 \\
\hline Sept. $4 \ldots \ldots$ & 145.60 & 1,140 & 5.60 & 89.60 & 1,051 & 3.93 \\
\hline Sept. 11.................. & 136.80 & 1,652 & 8.12 & 99.30 & 1,410 & 5.28 \\
\hline Sept. 18...................... & 100.00 & 1,112 & 5.47 & 108.80 & 1,726 & 6.46 \\
\hline Sept. $25 \ldots$ & 84.00 & 727 & 3.57 & 118.40 & 1,831 & 6.85 \\
\hline Oct. $\quad 2 \ldots$ & 82.40 & 475 & 2.34 & 912.00 & 1,621 & 6.08 \\
\hline Oct. $\quad 9 \ldots$ & 119.20 & 1,399 & 6.88 & 121.00 & 2,208 & 8.27 \\
\hline Oct. $16 \ldots$ & 132.00 & 3,430 & 16.83 & 115.20 & 2,780 & 10.42 \\
\hline Oct. 23 & 124.00 & 2,655 & 13.05 & 92.00 & 2,738 & 10.25 \\
\hline Oct. 30 & 111.20 & 3,195 & 15.71 & 75.20 & 2,107 & 7.89 \\
\hline 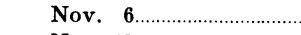 & 93.60 & …........* & …............ & 93.60 & 944 & 3.53 \\
\hline 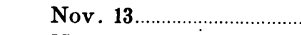 & $\ldots \ldots \ldots{ }^{*}$ & $\ldots \ldots \ldots \ldots$ & …........... & …........... & 1,485 & 5.56 \\
\hline \multirow[t]{2}{*}{ Nov. $20 \ldots$} & & $\ldots \ldots \ldots \ldots$ & $\ldots \ldots \ldots \ldots$ & ……...... & 1,164 & 4.36 \\
\hline & \multicolumn{3}{|c|}{1928} & \multicolumn{3}{|c|}{1929} \\
\hline Season's total.. & $\ldots \ldots \ldots \ldots{ }^{*}$ & $28,223 \dagger$ & $100.00 \dagger$ & .................. & $23,110 \dagger$ & $100.00 \dagger$ \\
\hline Aug. $\quad 7 \ldots$ & 65.60 & 515 & 1.82 & 216.00 & 573 & 2.48 \\
\hline Aug. 14 & 100.80 & 739 & 2.62 & 193.60 & 658 & 2.85 \\
\hline 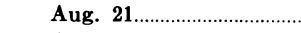 & 114.40 & 1,151 & 4.08 & 146,40 & 924 & 4.00 \\
\hline 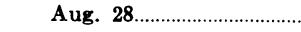 & 101.60 & 1,560 & 5.53 & 128.00 & 925 & 4.00 \\
\hline Sept. 4 & 94.40 & 1,326 & 4.70 & 98.40 & 957 & 4.14 \\
\hline 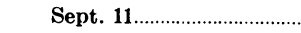 & 90.40 & 1,449 & 5.13 & 115.20 & 1,334 & 5.77 \\
\hline Sept. 18 & 102.40 & 1,444 & 5.12 & 127.20 & 1,313 & 5.68 \\
\hline Sept. 25 & 100.80 & 1,619 & 5.74 & 116.80 & 1,689 & 7.31 \\
\hline Oct. $\quad 2$ & 100.00 & 1,763 & 6.25 & 121.60 & 1,718 & 7.44 \\
\hline Oct. $\quad 9$ & 100.80 & 1,972 & 6.99 & 107.20 & 1,624 & 7.03 \\
\hline Oct. 16 & 97.60 & 2,250 & 7.97 & 91.20 & 1,618 & 7.00 \\
\hline Oct. $23 \ldots \ldots$. & 105.60 & 2,459 & 8.71 & 104.00 & 1,435 & 8. 37 \\
\hline Oct. 30 & 90.40 & 2,479 & 8. 78 & 119.20 & 2,122 & 9.18 \\
\hline 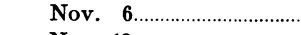 & 23.20 & 1,453 & 5.15 & 114.40 & 2,020 & 8.74 \\
\hline Nov. 13 & …….......... & 749 & 2.65 & 110.40 & 1,572 & 6.80 \\
\hline Nov. 20 & .............. & $1,128$. & 4.00 & 139.20 & 874 & 3.78 \\
\hline
\end{tabular}

* Dashes indicate no data available or insufficient data.

t Includes sales prior to August 1 and after November 20.

Sources of data:

Col. 1: Simple or unweighted weekly average price for lugs and crates of Cornichon, Emperor, Malaga, Thompson Seedless, and Tokay varieties multiplied by 80 to convert to approximate price per ton. Data from reference 8, $p .23-46$.

Cols. 4, 7, 10: True or weighted average prices for lugs and crates of varieties listed above and Red Malaga in addition, multiplied by 80 to convert to price per ton. Prices for 1927 from reference 2, p. 58-79; for 1928 from reference 9, p. 47-94; and for 1929 from reference 7 .

Col. 2: Estimates for Emperor, Malaga, Thompson Seedless, and Tokay varieties based upon inspections by the Federal-State Inspection Service from reference 8, p. 75, 76.

Cols. 5, 8, 11: Shipments of Emperor, Malaga, Red Malaga, Black Prince, Rose of Peru, Thompson Seedless, and Tokay varieties. Data for 1927 from reference 2, $p$. 20-25; for 1928 and 1929 from references 3 and 4 . 
It will have been observed that factors other than that of shipments have not been emphasized. While such other factors as supplies of eastern grapes, and seasonal movement and quality of all table grapes play a part in determining the season's average price of California table grapes, the greatest influence by far is that of total carlot shipments.

A number of factors not discussed in this article that might logically be expected to influence table-grape prices were studied but found to have had an effect too small to be apparent or else an effect obscured by other factors. The more important of these other factors were (1) United States production of certain other fruits, both individually and in combination with one another, (2) various indexes, such as those of factory payrolls, employment, and the price of foods, (3) the proportion of table-grape shipments consisting of different varieties, and (4) track holdings.

\section{BLACK-JUICE GRAPES}

As was true of table grapes, California shipments were found to have been the chief determinant of black-juice grape prices $^{11}$ in eastern markets. Moreover, the demand for black-juice grapes was found to be about as inelastic as that of table grapes (see page 104). Figure 3 shows how close the relation has been, during a period of nine years, between total inter and intrastate shipments of California black-juice grapes and weighted average annual New York deliveredauction prices adjusted for changes in the general level of all-commodity wholesale prices. The regression curve in this figure indicates that the elasticity of demand for black-juice grapes varies from about 0.8 to 0.9 with variations in shipments from about 25,000 to 31,000 carloads.

The greater divergence of the scatter from the regression curve in figure 3 as compared with that in figure 1 indicates that changes in the volume of shipments have accounted for a smaller part of changes in the price of black-juice grapes than in the case of table grapes. The fact that black-juice prices for 1925 and 1926 were so different, although the volume of shipments was practically the same, indicates a definite difference in demand in these two years. This suggests

\footnotetext{
11 In this analysis the weighted average price of New York deliveredauction sales of the following grapes was used: Alicante Bouschet, Carignane, Petite Sirah, Mission, Mataro and Zinfandel. These six varieties comprise, on an average, about 75 per cent of the annual shipments of black-juice grape shipments from California.
} 
a comparison of the available facts regarding these two marketing seasons as a means of discovering variables other than volume of shipments that may have affected prices. Figure 3 shows a similar, although greater, difference in demand in 1927 compared with 1928.

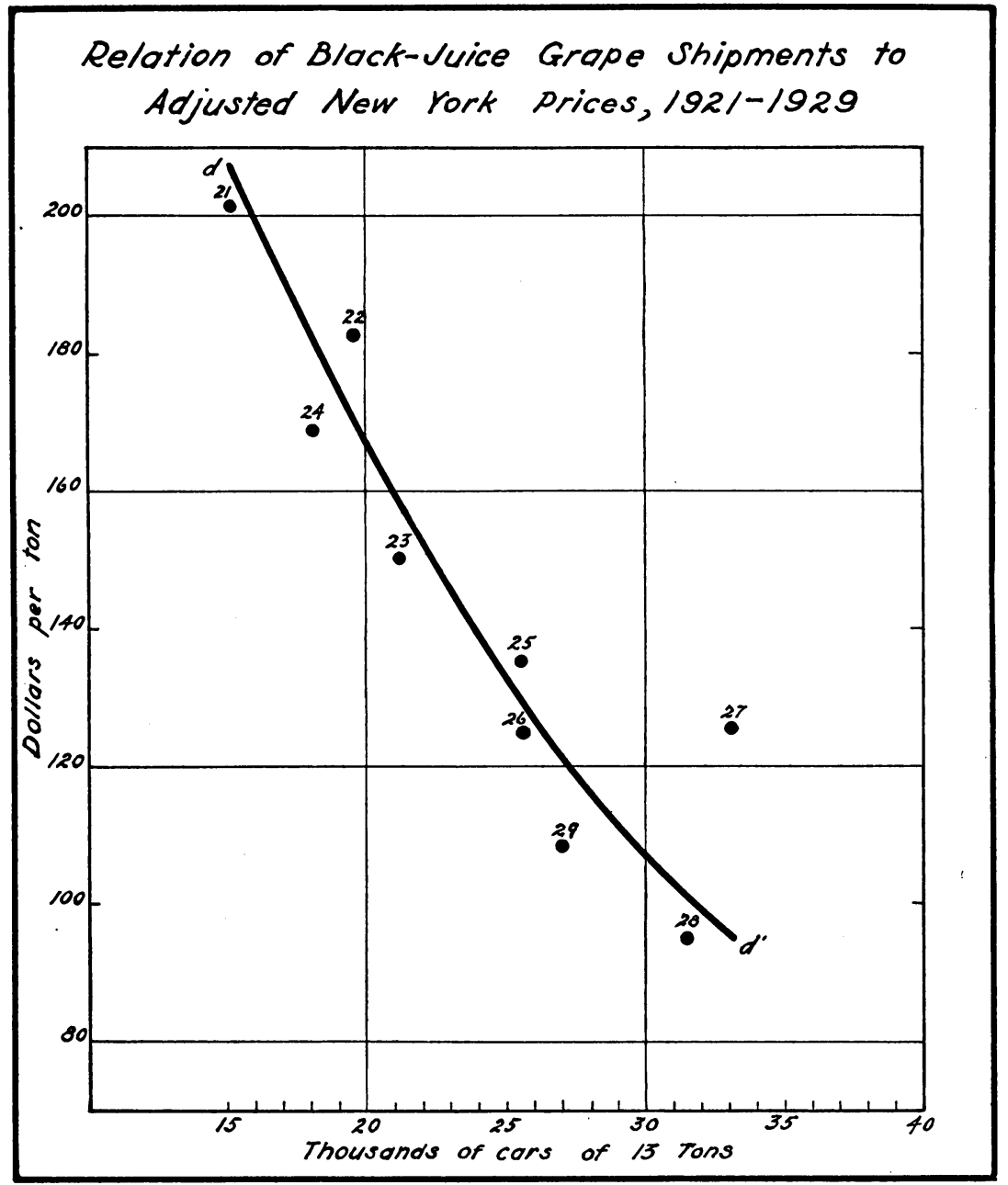

Fig. 3. Data from table 3.

By studying these four marketing seasons carefully with the aid of the general information available in trade literature, as well as the statistical record of California fresh-grape deals, a reasonable partial explanation of the causes of the differences in demand in 1925 compared with 1926 and in 1927 compared with 1928 was worked out. 
This, together with other analyses indicated that the more important factors affecting black-juice prices, other than the season's volume of shipments in recent years, have apparently been (1) timing of early black-juice shipments to demand in eastern markets, (2) volume and timing of Muscat shipments, and (3) quality of black-juice stock.

\section{TABLE 3}

Annual Shipments and Actual and Adjusted New York Delivered-Auction Prices of California Black-Juice Grapes, 1921-1929

\begin{tabular}{|c|c|c|c|}
\hline \multirow{3}{*}{ Crop year } & \multirow{2}{*}{$\begin{array}{l}\text { California } \\
\text { shipments }\end{array}$} & \multicolumn{2}{|c|}{ Price per ton } \\
\hline & & Unadjusted & Adjusted \\
\hline & 1 & $\mathscr{2}$ & 3 \\
\hline & carloads & dollars & dollars \\
\hline 1921. & 15,200 & 196.80 & 201.63 \\
\hline 1922 & 19,600 & 176.80 & 182.80 \\
\hline 1923 & 21,200 & 151.20 & 150.29 \\
\hline$\ldots$ & 18,100 & 165.60 & 168.80 \\
\hline $1925 \ldots \ldots \ldots \ldots \ldots$ & 25,500 & 140.00 & 135.26 \\
\hline $1926 \ldots \ldots$ & 25,600 & 124.80 & 124.80 \\
\hline $1927 \ldots$ & 33,100 & 120.00 & 125.80 \\
\hline 1928 & 31,500 & 92.80 & 95.00 \\
\hline $1929 \ldots \ldots \ldots$ & 27,000 & 104.80 & 108.60 \\
\hline
\end{tabular}

Sources of data:

Col. 1: Total shipments to the nearest hundred cars in carloads of approximately 13 tons net, both inter and intrastate, of all blackjuice varieties-Alicante Bouschet, Zinfandel, Carignane, Petite Sirah, Mission, and Mataro are the chief ones. Data for 1928 and 1929 increased 6 per cent to allow for heavier loadings per car. Data for 1921-1926 from reference $1, p .46,47$; for $1927-1929$ from same sources and same methods indicated in footnote 1, table 1, page 106.

Col. 2: True or weighted average prices per lug of New York delivered-auction sales through the first or second week in November for the varieties listed above. Converted to price per net ton at the rate of 80 lugs per ton. Data from source indicated in footnote 2, table 1, page 106 .

Col. 3: Prices adjusted to 1926 base by use of U. S. Bureau of Labor Statistics all-commodity index of wholesale prices for calendar years.

It is generally conceded by the best-informed marketing agencies that practically all California black-juice grapes shipped to eastern markets are used for wine-making. It is also common knowledge that the making of a good grade of wine requires a temperature conducive to proper fermentation. This study indicates that a weekly average mean temperature of $50^{\circ}$ to $60^{\circ} \mathrm{F}$ is apparently the range within which the most active buying of juice grapes takes place. It will be observed in table 4 that such a temperature usually starts to prevail in New York City anywhere from the first to the third week in October, the month of greatest demand and heaviest sales of juice grapes. Such temperatures generally prevail during a large part of 
this month. Judging by sales and unloads data in New York and Jersey City markets, buyers of juice stock usually allow a week to 10 days of such favorable temperature for wine-making to pass before they purchase any considerable quantities of juice grapes. Up to that time buyers appear to have usually been indifferent about purchasing juice stock.

TABLE 4

Weekly Average of Daily Mean Temperatures for New York City, in Degrees Fahrenheit, 1925-1929

\begin{tabular}{|c|c|c|c|c|c|c|}
\hline Week ending & 1925 & 1926 & 1927 & 1928 & 1929 & $\begin{array}{c}\text { Five- } \\
\text { year } \\
\text { average }\end{array}$ \\
\hline Aug. $\quad 7$ & 71.7 & 75.5 & 69.3 & 79.1 & 70.5 & 73.2 \\
\hline Aug. 14 & 74.4 & 76.7 & 70.4 & 75.7 & 73.0 & 74.0 \\
\hline Aug. $21 \ldots$ & 74.1 & 66.1 & 66.7 & 74.1 & 70.8 & 70.4 \\
\hline Aug. 28......... & 67.9 & 71.3 & 64.4 & 70.0 & 70.3 & 68.8 \\
\hline Sept. $4 \ldots$. & 71.9 & 64.7 & 67.4 & 74.4 & 78.3 & 71.3 \\
\hline Sept. $11 \ldots \ldots$ & 71.2 & 66.2 & 69.9 & 65.5 & 71.5 & 68.9 \\
\hline 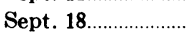 & 70.3 & 66.9 & 68.4 & 70.9 & 60.7 & 67.4 \\
\hline Sept' 25 & 62.4 & 63.9 & 62.7 & 66.1 & 65.7 & 64.2 \\
\hline Oct. $\quad 2 \ldots$ & 59.7 & 64.6 & 66.3 & 54.2 & 57.7 & 60.5 \\
\hline Oct. $\quad 9 \ldots$ & 55.5 & 54.4 & 68.1 & 60.2 & 53.4 & 58.3 \\
\hline Oct. $16 \ldots$ & 49.9 & 52.4 & 56.6 & 62.6 & 53.3 & 55.0 \\
\hline Oct. $23 \ldots \ldots \ldots \ldots$ & 47.9 & 49.4 & 52.8 & 63.9 & 57.0 & 54.2 \\
\hline Oct. 30 & 44.6 & 49.0 & 57.9 & 51.5 & 55.0 & 51.6 \\
\hline Nov. 6.................... & 44.9 & 48.4 & 52.4 & 47.9 & 49.3 & 48.6 \\
\hline Nov. $13 \ldots$ & 47.0 & 45.1 & 43.1 & 48.0 & 52.5 & 47.1 \\
\hline Nov. $20 \ldots$ & 46.7 & 41.3 & 50.8 & 50.7 & 42.4 & 46.4 \\
\hline Nov. $27 \ldots \ldots$ & 39.9 & 41.3 & 46.2 & 46.2 & 34.5 & 41.6 \\
\hline
\end{tabular}

Source of data: U. S. Dept. Agr. Climatological Data.

Study of the shaded areas in figures $4^{12}$ and 5 brings out the fact that in 1926 and 1928 sales and unloads of black-juice grapes lagged a week to two weeks behind arrival of shipments. This condition occurred because California black-juice grapes matured early and a considerable volume reached eastern markets before the proper temperature prevailed to create a strong demand for them. Apparently, because of this fact, prices opened at a lower level than they would have if heavy shipments had been delayed until demand had strengthened. The season's average price in both years was lower than the regression curve in figure 3 would lead one to expect from the season's total black-juice shipments. The tendency for prices to strengthen during the period of heavy sales in both 1926 and 1928 also suggests that demand, during the early part of the season, was not strong enough to support the heavy early arrivals.

12 In figure 4, weekly volume of auction sales of black-juice grapes in New York City were substituted for weekly unloads because there were no available unload statistics for seasons prior to 1927. 


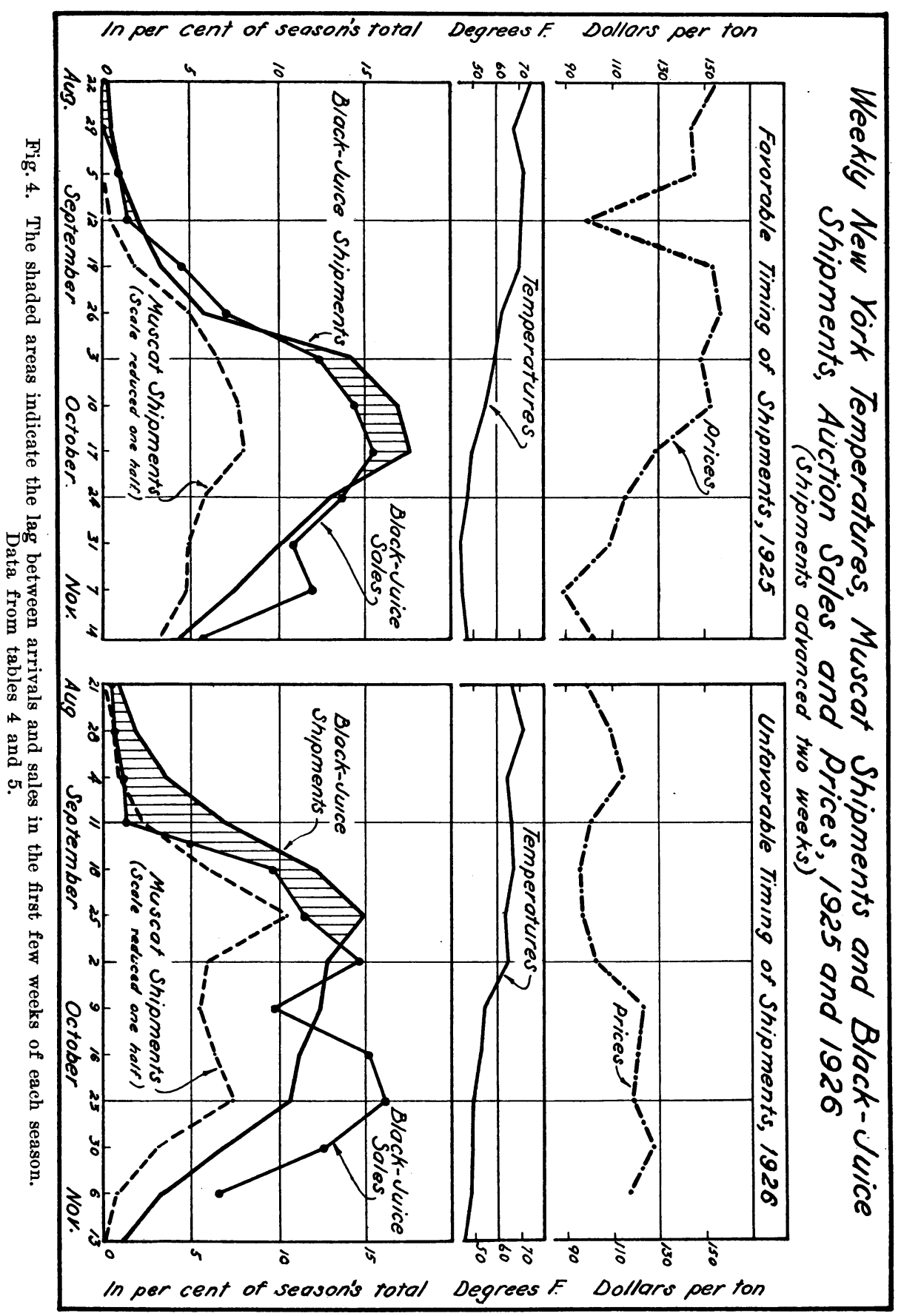




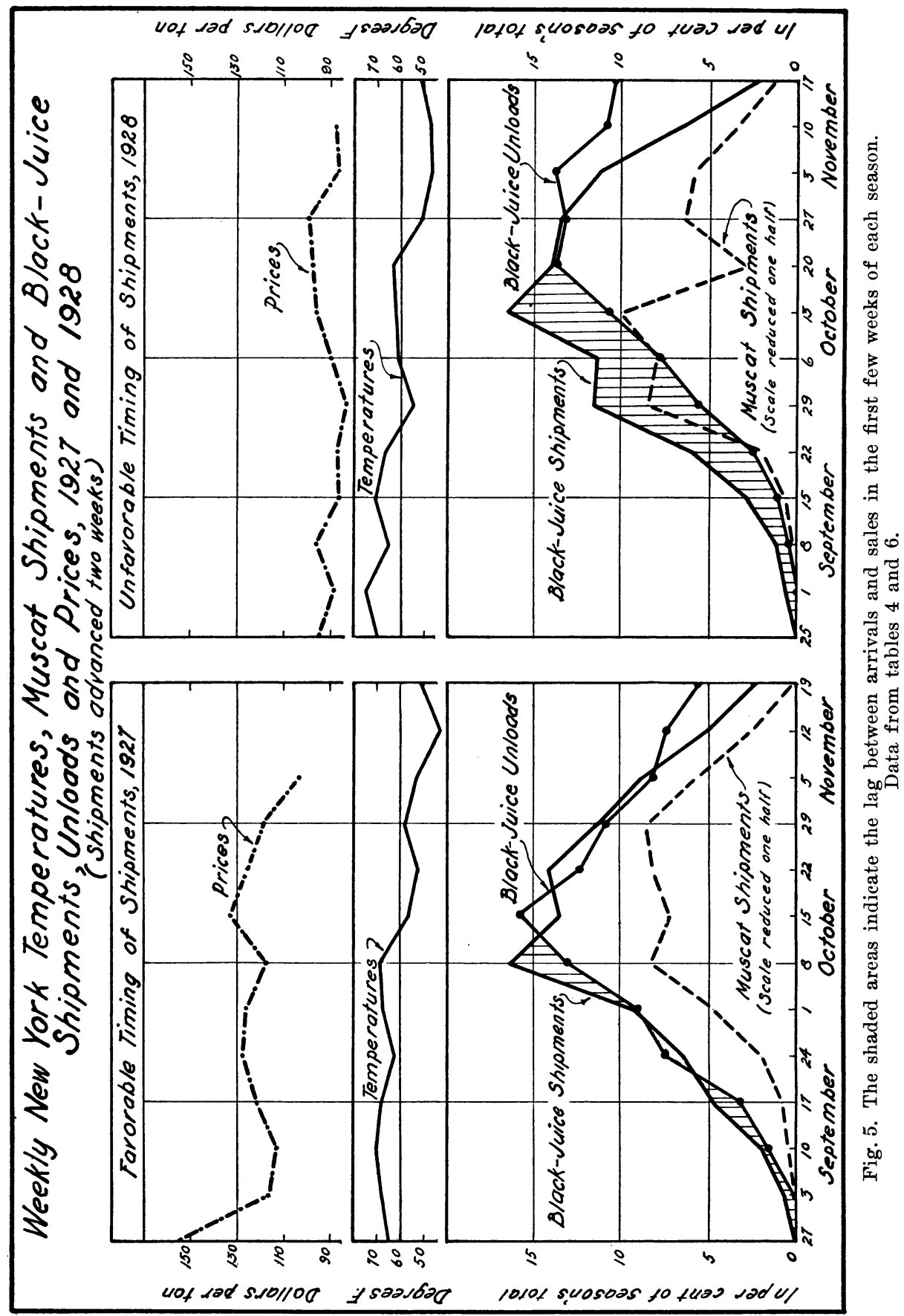


On the other hand, in years like 1925 and 1927 in which heavy arrivals in eastern markets did not occur until about the time when temperature conditions were favorable for wine-making, consumers appear to have been in the market ready to move juice grapes into consumption at better prices than could be expected earlier. Shipments to eastern markets in these two years were delayed either because of late-maturing crops or because early shipments were held back by shipping organizations. In both 1925 and 1927, there was favorable timing of early shipments to demand, unloads coinciding closely with arrivals from California. Correspondingly, prices were above the average to be expected for the quantities shipped, judging from the regression line in figure 3. Prices in 1925, however, were not as well maintained as in 1927. The sharp price decline in the latter part of the 1925 season was largely due to very unfavorable weather conditions-early snow and heavy frosts. During 1927 there appears to have been an exceptional demand for juice grapes, the causes of which have not been entirely explained.

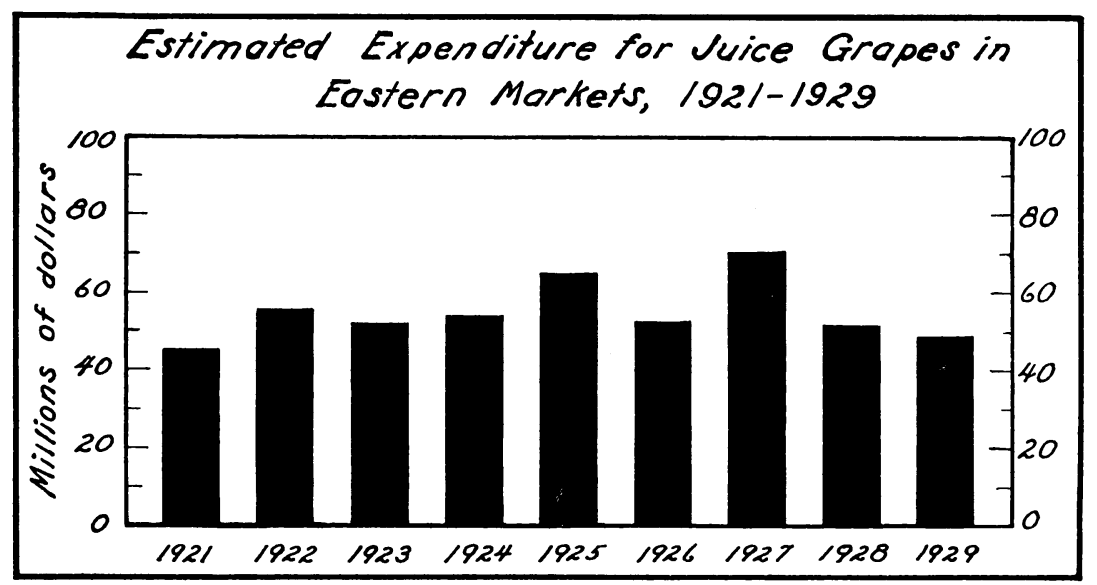

Fig. 6. Data based upon tables 3 and 7 and computed by adding the value of shipments of black-juice grapes, at their adjusted price, to the value of shipments of Muscats, at their adjusted price.

Perhaps the most important factor affecting black-juice grape prices remaining to be discussed is the volume and timing of fresh Muscat shipments. According to the trade, fresh Muscats have been extensively used in the East for blending with black-juice varieties, partly because they have been low priced and partly because many consider that they improve the color and taste of wine. Information from those acquainted with wine-making in the East indicates that 
no set proportion of black and white juice is used in making a blend. When Muscat supplies are plentiful owing to heavy shipments early in the season, and their price more attractive to buyers than that of black-juice grapes, the proportion of Muscats used in blending is presumably increased.

The hypothesis that Muscats are used to hold down the aggregate cost of the wine made seems to be supported to some extent by figure 6, which gives the total outlay, based on New York auction prices, for all juice stock by years. With the exception of 1925 and 1927, the total outlay per season has remained fairly uniform, although a slight downward movement may be occurring. As black-juice grape prices have declined greatly since 1925 with increased shipments, apparently more of them have been substituted for Muscats.

Figures 4 and 5 enable one to see the relation between weekly Muscat shipments and black-juice prices, shipments, and un'oads in four recent years. In 1925 and 1927, years when prices of black-juice grapes were most favorable, heavy Muscat shipments did not arrive in eastern markets before black-juice grapes were moving readily into consumption. Because shipments of Muscats were favorably timed to the demand for black-juice grapes they apparently did not tend to depress black-juice prices unduly. During the 1926 season, although black-juice shipments were not properly timed to demand, Muscat shipments arrived in the East after the demand for black-juice grapes had developed. Black-juice prices, therefore, were probably prevented from falling lower than they did. The season of 1928 illustrates the tendency for substantial arrivals of Muscats before the demand for wine-making had become well developed to add to the unfavorable conditions created by early shipments of black-juice grapes. The bulk of Muscat shipments in 1928 arrived in eastern markets before black-juice grapes were moving most freely into consumption, and thereby apparently depressed the price of both classes of grapes.

Quality of black-juice grapes has obviously had some influence upon their prices. In 1926 the good quality of black-juice grapes plus late Muscat shipments aided materially in preventing prices from remaining on a low level for the entire season. Since juice grapes are not used for direct table consumption, however, external appearance probably affects their prices less than it does table-grape prices. 
TABLE 5

Weekly Prices, Auction Sales, and Shipments of Black-Juice Grapes, AND SHIPMENTS OF Muscats, 1925 AND 1926

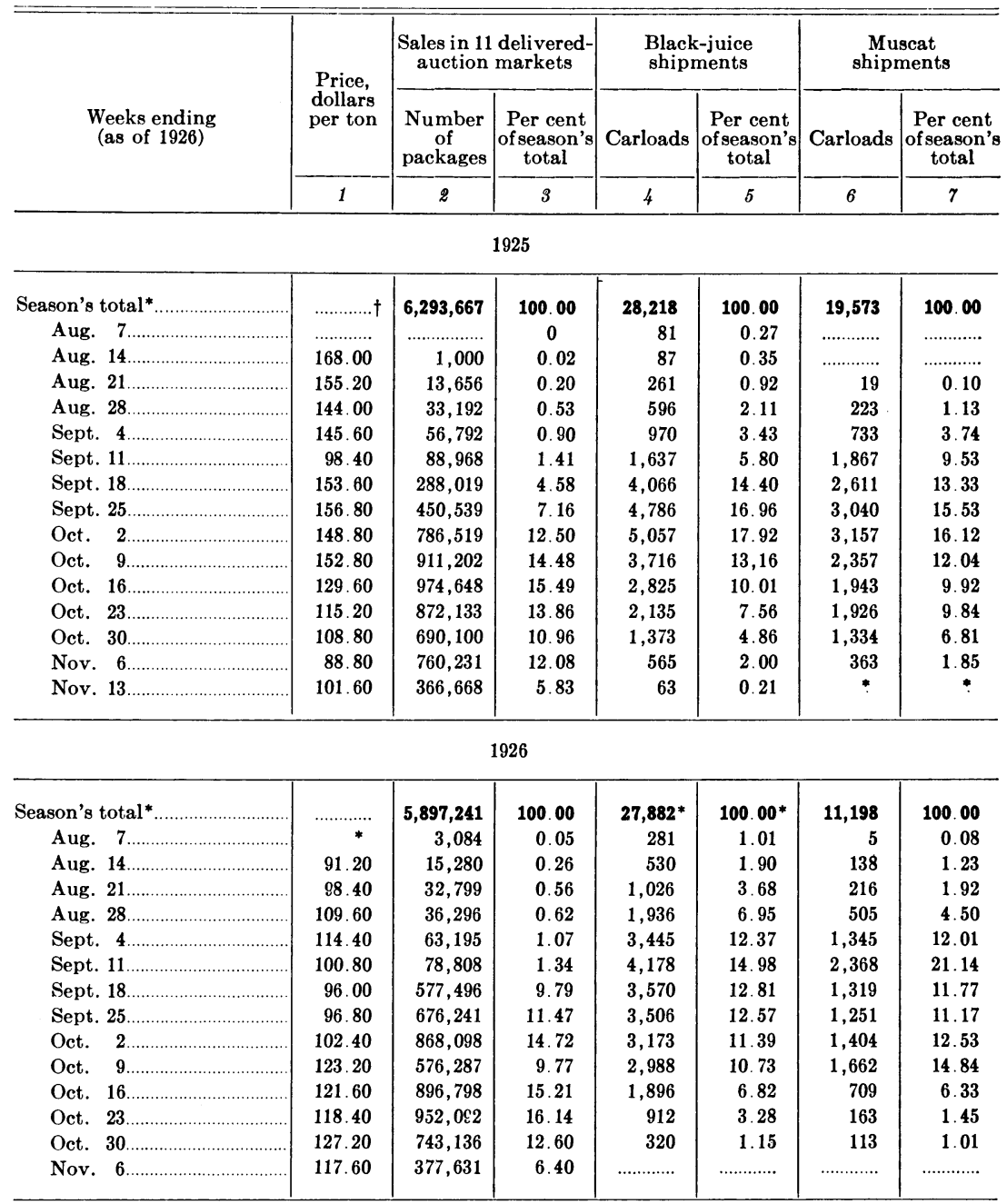

* Data for the period August 1 through November 13 are identical with the season's totals except in the case of black-juice shipments for 1926 , which a mounted to 27,781 cars for that period compared with the season's total of 27,882 .

† Dashes indicate no data available or insufficient data.

Sources of data:

Col. 1: Simple or unweighted weekly average price for lugs of the chief black-juice varietiesAlicante Bouschet, Carignane, Zinfandel, Petite Sirah, Mission and Mataro-multiplied by 80 to convert to approximate price per ton. Data from reference 8, p. 23-46.

Col. 2: Weekly totals of sales of the varieties listed above on the eleven delivered-auction markets listed in footnote 6, page 103. Data from reference $8, p .23-46$.

Cols. 4 and 6: Include a few hundred cars of white-wine varieties in both 1925 and 1926. Data for 1925 from reference $1, p .71$ and for 1926 from reference $8, p .75-76$. 
TABLE 6

Weekly Shipments of Black-Juice Grapes and Unloads and Prices. in New York and WeEkly Muscat Shipments, 1927-1929

\begin{tabular}{|c|c|c|c|c|c|c|c|}
\hline \multirow{4}{*}{$\begin{array}{l}\text { Weeks ending } \\
\text { (as of 1927) }\end{array}$} & \multirow{3}{*}{$\begin{array}{l}\text { Price, } \\
\text { dollars } \\
\text { per ton }\end{array}$} & \multirow{2}{*}{\multicolumn{2}{|c|}{$\begin{array}{c}\text { Unloads of } \\
\text { black-juice grapes }\end{array}$}} & \multicolumn{4}{|c|}{ Interstate shipments } \\
\hline & & & & \multicolumn{2}{|c|}{ Black-juice } & \multicolumn{2}{|c|}{ Muscat } \\
\hline & & Carloads & $\mid \begin{array}{c}\text { Per cent } \\
\text { of season's } \\
\text { total }\end{array}$ & Carloads & $\left|\begin{array}{c}\text { Per cent } \\
\text { of season's } \\
\text { total }\end{array}\right|$ & Carloads & $\begin{array}{c}\text { Per cent } \\
\text { of season's } \\
\text { total }\end{array}$ \\
\hline & \multicolumn{7}{|c|}{1927} \\
\hline 1 & 2 & 3 & 4 & 5 & 6 & 7 & 8 \\
\hline 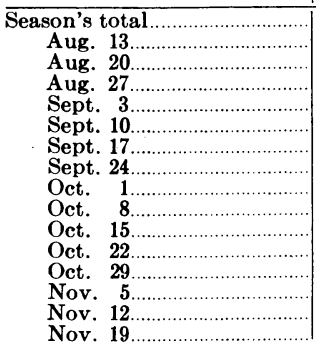 & $\begin{array}{l}\ldots \ldots \ldots . . \\
\ldots \ldots \ldots \ldots . . \\
155.20 \\
116.80 \\
113.60 \\
121.60 \\
127.20 \\
126.40 \\
118.40 \\
133.60 \\
126.40 \\
118.40 \\
104.80 \\
\ldots \ldots \ldots \ldots . .\end{array}$ & $\begin{array}{r}8,069 \\
13 \ldots \ldots \ldots \\
131 \\
253 \\
612 \\
730 \\
1,058 \\
1,279 \\
996 \\
827 \\
662 \\
618 \\
456\end{array}$ & $\begin{array}{r}100.00 \\
\ldots \ldots \ldots \ldots . . . \\
\ldots \ldots \ldots \ldots . . . \\
0.22 \\
1.62 \\
3.13 \\
7.58 \\
9.04 \\
13.11 \\
15.85 \\
12.34 \\
10.24 \\
8.20 \\
7.65 \\
5.65\end{array}$ & $\begin{array}{r}29,140 \dagger \\
28 \\
261 \\
748 \\
1,302 \\
1,909 \\
3,484 \\
4,752 \\
3,933 \\
4,282 \\
3,317 \\
2,601 \\
1,493 \\
691 \\
245 \\
78\end{array}$ & $\begin{array}{r}100.00 \dagger \\
0.09 \\
0.89 \\
2.56 \\
4.46 \\
6.55 \\
12.00 \\
16.30 \\
13.50 \\
14.70 \\
11.40 \\
8.92 \\
5.12 \\
2.37 \\
0.84 \\
0.27\end{array}$ & $\begin{array}{r}15,216 \\
16 \\
149 \\
272 \\
640 \\
1,434 \\
2,628 \\
2,235 \\
2,533 \\
2,584 \\
1,741 \\
747 \\
143 \\
83 \\
5\end{array}$ & $\begin{array}{r}100.00 \\
0.11 \\
0.97 \\
1.78 \\
4.21 \\
9.43 \\
17.28 \\
14.69 \\
16.65 \\
16.98 \\
11.44 \\
4.91 \\
0.93 \\
0.55 \\
0.03\end{array}$ \\
\hline \multirow{2}{*}{ Nov. 19.} & \multicolumn{7}{|c|}{1928} \\
\hline & 9 & 10 & 11 & 12 & 13 & 14 & 15 \\
\hline 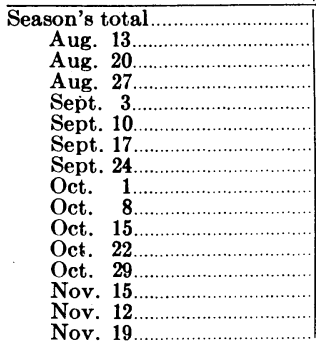 & $\begin{array}{r}79.20 \\
97.60 \\
94.40 \\
88.80 \\
96.00 \\
86.40 \\
87.20 \\
84.00 \\
90.40 \\
96.80 \\
98.40 \\
99.20 \\
87.20 \\
88.00 \\
\ldots \ldots \ldots . .\end{array}$ & $\begin{array}{r}5,664 \\
2 \\
3 \\
11 \\
22 \\
27 \\
62 \\
143 \\
315 \\
440 \\
668 \\
780 \\
757 \\
789 \\
621 \\
573\end{array}$ & $\begin{array}{r}100.00 \\
0.04 \\
0.05 \\
0.19 \\
0.38 \\
0.47 \\
1.09 \\
2.52 \\
5.56 \\
7.76 \\
11.79 \\
13.78 \\
13.37 \\
13.94 \\
10.97 \\
10.11\end{array}$ & $\begin{array}{r}26,048 \dagger \\
37 \\
197 \\
339 \\
775 \\
1,586 \\
3,031 \\
3,023 \\
4,333 \\
3,650 \\
3,541 \\
2,972 \\
1,729 \\
642 \\
115 \\
26\end{array}$ & $\begin{array}{c}100.00 \dagger \\
0.14 \\
0.76 \\
1.30 \\
2.97 \\
6.08 \\
11.63 \\
11.60 \\
16.63 \\
14.01 \\
13.59 \\
11.40 \\
6.63 \\
2.46 \\
0.44 \\
0.09\end{array}$ & $\begin{array}{r}14,170 \\
14 \\
56 \\
201 \\
596 \\
2,441 \\
2,238 \\
2,872 \\
837 \\
1,832 \\
1.667 \\
1,009 \\
347 \\
47 \\
9\end{array}$ & $\begin{array}{r}100.00 \\
\ldots \ldots .10 \\
0.39 \\
1.42 \\
4.21 \\
17.23 \\
15.79 \\
20.27 \\
5.91 \\
12.93 \\
11.77 \\
7.12 \\
2.44 \\
0.33 \\
0.06\end{array}$ \\
\hline \multirow{2}{*}{ Nov. 19} & \multicolumn{7}{|c|}{1929} \\
\hline & 16 & 17 & 18 & 19 & 20 & 21 & 22 \\
\hline $\begin{array}{r}\text { Season's total.. } \\
\text { Aug. } 13 \ldots \ldots \\
\text { Aug. } 20 \ldots \ldots \\
\text { Aug. } 27 \ldots \ldots \\
\text { Sept. } 3 \ldots \ldots \\
\text { Sept. } 10 \ldots \ldots \\
\text { Sept. } 17 \ldots \ldots \\
\text { Sept. } 24 \ldots \ldots \\
\text { Oct. } 1 \ldots \ldots \\
\text { Oct. } 8 . \ldots \\
\text { Oct. } 15 \ldots \ldots \\
\text { Oct. } 22 \ldots \ldots \\
\text { Oct. } 29 \ldots \ldots \\
\text { Nov. } 5 \ldots \ldots \\
\text { Nov. } 12 \ldots \ldots \\
\text { Nov. } 19 \ldots \ldots\end{array}$ & $\begin{array}{r}135.20 \\
132.80 \\
99.20 \\
103.20 \\
106.40 \\
104.80 \\
90.40 \\
94.40 \\
103.20 \\
113.60 \\
107.20 \\
102.40 \\
122.40\end{array}$ & $\begin{array}{r}7,632 \\
\ldots \ldots \ldots . . . \\
2 \ldots \\
17 \\
20 \\
54 \\
104 \\
254 \\
421 \\
614 \\
1,139 \\
1,099 \\
1,094 \\
1,064 \\
859\end{array}$ & $\begin{array}{r}100.00 \\
\ldots \ldots \ldots . . \\
\ldots \ldots \ldots .02 \\
0.22 \\
0.26 \\
0.71 \\
1.36 \\
3.32 \\
5.52 \\
8.05 \\
14.93 \\
14.39 \\
14.34 \\
13.95 \\
11.25\end{array}$ & $\begin{array}{r}24,294 \dagger \\
7 \\
149 \\
412 \\
837 \\
1,625 \\
2,548 \\
4,094 \\
3,724 \\
2,666 \\
3,272 \\
2,747 \\
1,678 \\
455 \\
80\end{array}$ & $\begin{array}{r}100.00 \dagger \\
\ldots \ldots .02 \\
0.61 \\
1.69 \\
3.44 \\
6.68 \\
10.49 \\
16.86 \\
15.33 \\
10.98 \\
13.46 \\
11.31 \\
6.91 \\
1.87 \\
0.33\end{array}$ & $\begin{array}{r}8,855 \\
\ldots \ldots \ldots . . . \\
4 \\
19 \\
27 \\
264 \\
829 \\
2,295 \\
1,592 \\
1,390 \\
1,207 \\
761 \\
316 \\
107 \\
43\end{array}$ & $\begin{array}{r}100.00 \\
\ldots \ldots \ldots \ldots . . \\
\ldots \ldots .04 \\
0.21 \\
0.30 \\
2.98 \\
9.36 \\
25.92 \\
17.98 \\
15.70 \\
13.64 \\
8.60 \\
3.57 \\
1.21 \\
0.47\end{array}$ \\
\hline
\end{tabular}

* Dashes indicate no data available or insufficient data

+ Prior to August 7 only one car of black-juice grapes was shipped in 1927 , only 21 cars in 1928, and none in 1929. In all other cases the difference between the season's total and the total from August 7 to November 19 are figures for the season after November 19 .

Sources of data:

Cols, 2, 9, and 16: True or weighted average New York delivered-auction prices per lug of chief black-juice varieties-Alicante Bouschet, Zinfandel, Carignane, Petite Sirah, Mission and Mataromultiplied by 80 to convert to price per ton. Data for 1927 from reference $2, p$. $75-79$; for 1928 from reference $9, p .47-98$, and for 1929 compiled from reference 7 , supplemented by reference 4.

Cols. 3, 10, and 17: Unloads in New York and Jersey City compiled from daily Market News on Grapes issued by U. S. Dept. Agr. Bur. Agr. Econ. from Fresno. See reference 7, for 1929.

Cols. 5 and 7 : Compiled from reference $2, p .20-26$.

Cols. 12, 14, 19, and 21: Compiled from references 3 and 4. 
Undoubtedly, there are other factors which have influenced the price of black-juice grapes, such as strikes (e.g., the truckmen's strike in New York City in 1929), racketeering, trends in prohibition enforcement, and psychological peculiarities of purchasers in eastern juice markets. Some of these factors are unpredictable, but no doubt they have had considerable influence on black-juice grape prices at times.

\section{MUSCATS}

In pre-war days most California Muscats were dried and very few were shipped fresh to eastern markets. Since the War, however, in response to eastern demand for juice grapes and because of decreased demand for Muscat raisins, California shipments of fresh Muscats increased very rapidly. Table 7 shows that only 3,300 cars were shipped in 1921, as compared with the peak of 19,300 carloads in 1925. Since 1925, Muscat shipments from year to year have fluctuated greatly with no trend particularly evident. However the plentifulness of black-juice grapes may be sufficient to restrict Muscat shipments in the future.

Although a few fresh Muscats are sold as table stock, a very large majority are utilized for juice purposes. During the years covered in this study, Muscats alone have comprised some 80 per cent of the total shipments of California white-juice grapes, and shipments and prices of this one variety are believed to be fairly representative of white-juice grapes as a class.

Figure 7 shows that fresh Muscat shipments have apparently been the chief factor affecting eastern prices of this variety, but it also indicates that changes in demand have had an important influence on prices. The regression curve indicates that the demand for fresh Muscat grapes is very elastic. Hence the total sales value of these grapes normally is much greater for heavy shipments than for light. This is quite in contrast with the somewhat inelastic demand for table and black-juice grapes (see pages 104 and 111) and the very inelastic domestic demand for raisins. ${ }^{13}$ The elasticity of demand indicated by the curve in figure 7 varies from about 2.0 with shipments of 8,000 to 10,000 carloads of Muscats to about 1.4 with shipments of 15,000 carloads or somewhat less. Demand is most elastic when shipments are small and prices high. The very elastic demand for fresh Muscats may be partly accounted for by the fact that a majority of eastern

\footnotetext{
13 See accompanying paper: Shear, S. W. and R. M. Howe. Factors affecting California raisin sales and prices, 1922-1929, Hilgardia 6:78. 1931.
} 
juice-stock buyers probably prefer black-juice grapes if the price is relatively low compared with Muscat prices, which has been the case normally in recent years with heavy shipments of black-juice grapes. In addition the regression curve in figure 7 suggests that there may be enough buyers who prefer Muscat wine or blends with black-juice so that they are willing to buy 8,000 to 12,000 carloads at moderate prices even when black-juice grapes are about the same price.

\section{Pelation of Muscat Grape Shipments to}

\section{Adjusted New York Prices, 1921-1929}

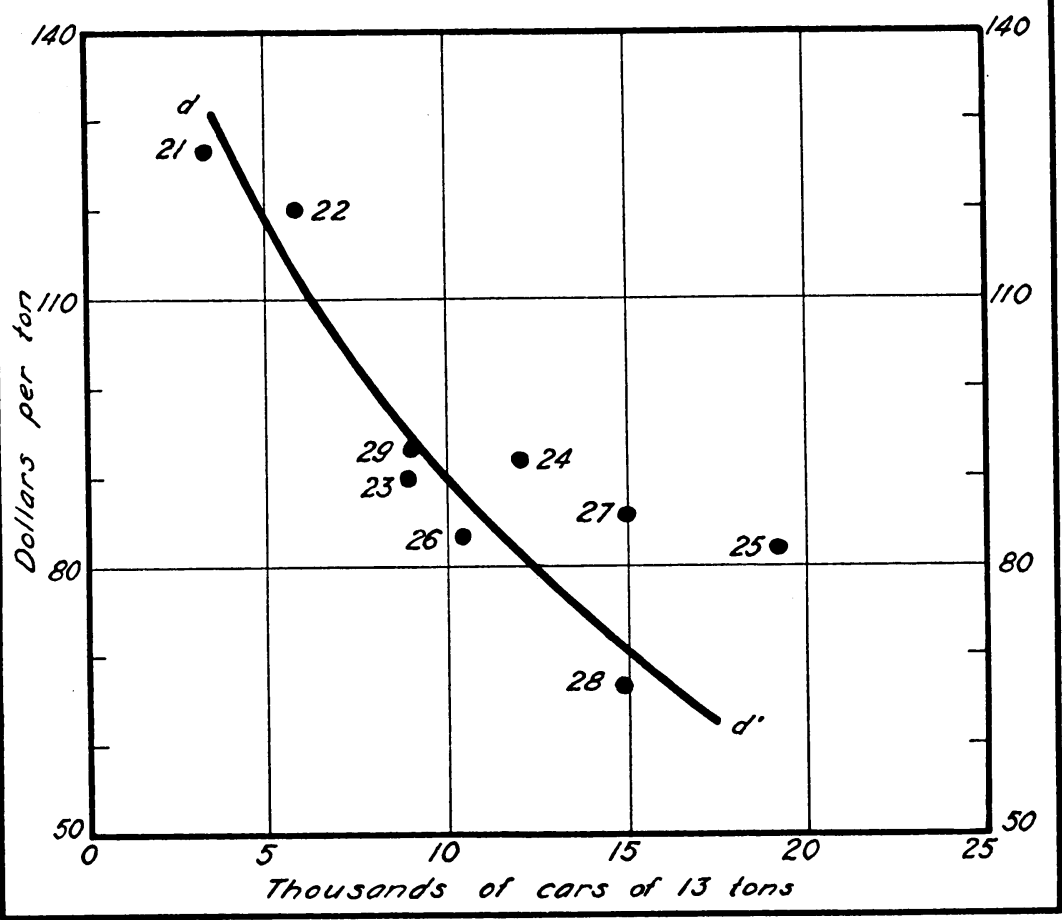

Fig. 7. Data from table 7.

Because Muscat grapes are mostly utilized for wine-making by eastern buyers, one would logically expect to find changes in demand similar to those for black-juice grapes. Comparison of figures 3 and 7 establishes this presumption as a fact. There have been very evident and significant similarities in changes in the demand for these two classes of juice grapes in recent years. Figures 3 and 7 both indicate 
that there was a much greater demand for juice grapes in 1925 than in 1926. Almost identically the same quantities of black-juice grapes were sold in 1925 as in 1926 but at an average of $\$ 10$ more a ton than in 1926. On the other hand fresh Muscats averaged almost the same price in 1925 as in 1926 although shipments in 1925 were nearly double those in 1926.

Prices of black-juice grapes in 1927, a year of exceptionally heavy demand for juice stock, averaged approximately $\$ 30$ a ton above the prices received for 1928 shipments, which lacked only about 2,000 cars of being as large as 1927 shipments. A strikingly similar situation prevailed for fresh Muscats. Although practically the same number of carloads of fresh Muscats were shipped in both of these years, their price in 1927 averaged nearly $\$ 20$ a ton above the average of 1928 .

Figure 7 also brings out the fact that the demand for fresh Muscats in 1924 was noticeably better than in 1923, since substantially more Muscats were shipped in 1924 at a slightly higher price than in 1923. It is also evident that eastern demand for fresh Muscats was about the same in 1929 as in 1923 and considerably less than in 1924, 1925, and 1927. The demand for black-juice grapes was also poor in 1929. However, it may not have been much poorer than the level of demand that some well-informed men in the juice-grape marketing business fear may prevail during the next few years. Preliminary data indicate that the demand for black-juice grapes in 1930 was just about the same as in 1928 and in 1929, while the demand for fresh Muscats in 1930 appears to have been noticeably better than in 1929, perhaps because Muscat shipments were so small compared with black-juice grapes. ${ }^{14}$

The most important factors other than shipments that appear to account largely for the price residuals from the regression curve in figure 7 are, (1) timing of Muscat shipments to demand, (2) the quantity ratio between black-juice grapes and Muscat shipments, (3) the quality, and (4) the general price level. The discussion of the influence of similar factors on black-juice grape prices (see pages 113-118) in general applies so well to fresh Muscat shipments, that further discussion of these factors has been omitted here except as regards the relation of temperatures in eastern markets to the demand for fresh Muscats.

\footnotetext{
14 Preliminary data indicate that about 29,200 carloads of California blackjuice grapes were shipped in 1930, the average New York delivered-auction price being about $\$ 89$ a ton actual or $\$ 103$ adjusted. About 8,700 carloads of Muscats moved at a price of about $\$ 88$ a ton actual or $\$ 102$ adjusted.
} 
Temperature appears to have greatly influenced the sale and movement into consumption of fresh Muscats in eastern markets in the same way as in the case of black-juice grapes. Muscats do not usually bring a favorable price until favorable temperatures prevail. Not until mean temperatures in New York City have remained between $50^{\circ}$ and $60^{\circ} \mathrm{F}$ for a week to ten days, have a great many Muscats been sold, and when heavy shipments of Muscats have arrived in eastern markets much before favorable temperatures occur, as in 1928, prices have suffered. On the other hand, in years when Muscats have reached eastern markets after favorable temperatures had prevailed and black-juice grapes had started to move readily into consumption, their price was considerably higher.

TABLE 7

Annual Shipments and Actual and Adjusted New York Delivered-Auction Prices of California Muscat Grapes, 1921-1929

\begin{tabular}{|c|c|c|c|}
\hline \multirow{3}{*}{ Crop year } & \multirow{2}{*}{$\begin{array}{l}\text { California } \\
\text { shipments }\end{array}$} & \multicolumn{2}{|c|}{ Price per ton } \\
\hline & & Unadjusted & Adjusted \\
\hline & 1 & 2 & $s$ \\
\hline & carloads & dollars & dollars \\
\hline $1921 .$. & 3,300 & 123.20 & 126.22 \\
\hline 1922. & 5,800 & 116.00 & 119.95 \\
\hline $1923 \ldots$ & 8,900 & 90.40 & 89.86 \\
\hline $1924 \ldots$ & 12,000 & 90.40 & 92.15 \\
\hline 1925 & 19,300 & 85.60 & 82.70 \\
\hline 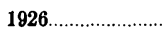 & 10,300 & 83.20 & 83.20 \\
\hline $1927 \ldots$ & 15,000 & 81.60 & 85.53 \\
\hline $1928 \ldots \ldots \ldots \ldots$ & 14,900 & 65.00 & 66.53 \\
\hline 1929 & 9,000 & 89.60 & 92.85 \\
\hline
\end{tabular}

Sources of data:

Col. 1: Total shipments to the nearest hundred, both inter and intrastate, in carloads approximately 13 tons net. Data for 1928 and 1929 increased 6 per cent to allow for heavier loadings per car. Source of data indicated in footnote 1, table 1 , page 106 .

Col. 2: Weighted average prices for New York deliveredauction sales. Source of data indicated in footnote 2, table 1 , page 106.

Col. 3: Prices adjusted to 1926 level by Bureau of Labor Statistics all-commodity index of wholesale prices for calendar years.

Most of the California Muscat vineyards were originally planted for raisin production, and before the War fresh shipments took only a small part of the crop. The percentage of the total production of Muscat grapes shipped fresh, however, rose rapidly after the War from about 5 per cent in 1921 to a peak of approximately 70 per cent in 1925 . In 1928 it was 60 per cent but in other recent years it has varied from about 40 to 45 per cent. 
Obviously many growers have been exercising the option of either drying their Muscats or of selling them to the fresh grape market. As a result, in recent years when prevailing prices and advances for raisins were small compared with expected returns from fresh shipments, fresh Muscat shipments have been large, as in 1927 and 1928. On the other hand, when the price of the dried product has appeared relatively more favorable, more have been dried and fewer carloads have been shipped fresh.

TABLE 8

Opening Prices of Fresh and Dried Muscat Grapes

\begin{tabular}{|c|c|c|}
\hline \multirow[t]{2}{*}{ Crop year } & $\begin{array}{l}\text { Fresh Muscats, } \\
\text { opening price, } \\
\text { dollars per ton }\end{array}$ & $\begin{array}{c}\text { Muscat raisins, } \\
\text { cents } \\
\text { per pound }\end{array}$ \\
\hline & 1 & $\mathscr{2}$ \\
\hline $1921 \ldots \ldots \ldots \ldots$ & $\ldots{ }^{*}$ & 16.7 \\
\hline 1922 & $\ldots{ }^{*}$ & 10.3 \\
\hline 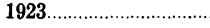 & 77 & 7.5 \\
\hline $1924 \ldots \ldots \ldots \ldots \ldots$ & 67 & 6.3 \\
\hline $1825 \ldots$ & 90 & 6.3 \\
\hline $1926 \ldots \ldots \ldots$ & 85 & 7.0 \\
\hline 1927 & 81 & 6.6 \\
\hline 1928 & 59 & 4.4 \\
\hline 1929 & 98 & 6.5 \\
\hline
\end{tabular}

* Adequate data not available.

Sources of data:

Col. 1: Simple or unweighted arithmetic average of sales of lugs during the first three weeks of each season in the eleven delivered-auction markets multiplied by 80 to convert to price per ton. The eleven delivered-auction market quotations for Muscats were selected in preference to the New York delivered-auction quotations in order to obtain an earlier average opening price. Data from reference 12, $p .26$; reference 2, p. 68; and reference 10, p. 42 .

Col. 2: Simple or unweighted average of the July, August, September, and October quotations for 25-pound Sun-Maid Puffed Bakery type. Compiled from data made available by the Sun-Maid Association.

Figure 8 shows graphically how this tendency has worked oút in the past. The upper scatter depicts the relation between the opening price of raisins and the opening price of fresh Muscats in the eleven eastern delivered-auction markets. There has been a tendency, as the scatter indicates, for the prices prevailing for the two different kinds of uses to strike at some equality. However, when the residuals from the curve in the upper figure were plotted against fresh-Muscat shipments, it was found that in years in which the opening price for raisins was low with respect to the prevailing prices for fresh Muscats in eastern markets, more Muscats were shipped fresh, and vice versa. 
Relation of Opening Prices of Fresh Muscats to (Sec.Al Opening Price of Dried Raisins and to (Sec B) Fresh Muscat Shipments $1923-1929$
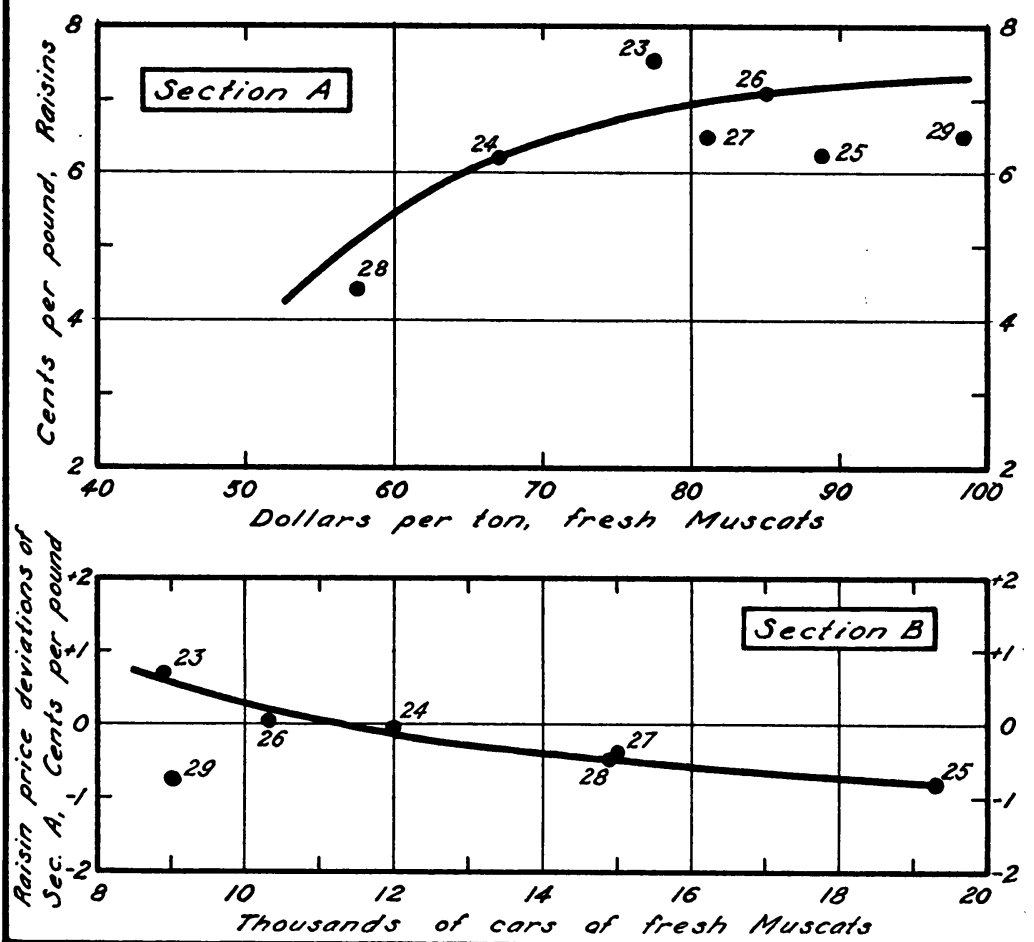

Fig. 8. Data from tables 7 and 8. 
Although the 1929 season appears to be an exception to this explanation in reality it is not, for, from the second week in September to the second week in October many Muscats were dried instead of shipped fresh because of the promise unfulfilled, of a bonus of 1 cent a pound on Muscat raisins offered by the Grape Stabilization Board $^{15}$ to reduce fresh Muscat shipments and thereby lessen competition with black-juice grapes in eastern markets. Naturally, more Muscats were dried and fewer shipped fresh than would otherwise have been the case. Only about 9,000 cars of fresh Muscats were shipped as compared with 15,000 in 1928, and prices secured in eastern markets were relatively higher than those received for the Muscats dried. Only about 45 per cent of California Muscat grape production was shipped fresh in 1929 compared with over 60 per cent in 1928.

\section{SUMMARY}

Similar, somewhat related, but slightly different factors account for changes in the annual average prices of each class of California grapes in eastern markets during the years 1921 through 1929 . The chief factor determining the annual average adjusted price of each class of grapes-table, black-juice, and white-juice-has been the season's total shipments. Shipments for the season have been much more influential in determining the season's average price in the case of table grapes, however, than in the cases of black-juice grapes and of Muscats. This seems to be primarily because shipments of table grapes have been better timed to meet the current needs of eastern markets than have those of juice grapes.

15 In the third week of August, 1929, the Federal Farm Board announced that it was taking part in a financing program whereby credit from the Farm Board and California banks amounting to 9 million dollars would be made available to Sun-Maid to be used for advances on the basis of 3 cents a pound for both Thompsons and Muscats to raisin growers who belonged to or pooled with SunMaid. In the second week of September, 1929, the Grape Stabilization Corporation announced that it would provide an additional advance of 1 cent a pound on Muscat raisins to this same group of growers. This one-cent bonus was designed to increase the quantity of Muscats dried and thereby decrease fresh Muscat shipments, thus reducing competition with black-juice grapes which have no alternative use other than as juice grapes. Presumably it was to be secured from assessments upon shipments of black-juice grapes, the class of grapes to be benefited most.

After getting many Muscat growers to dry their grapes by offering them this extra cent a pound, in the second week of October, 1929, the Grape Stabilization Corporation announced that it did not have the money to meet its agreement and hence the bonus could not be paid. (See California Fruit News 80 (2146) $p$. 3 and 6 , Aug. 24, 1929; 80 (2149) p. 3, Sept. 14, 1929; and 80, (2153) p. 3 and 6 , October 12, 1929). 
The demand for black-juice grapes and for table grapes at the quantities marketed in recent years has been somewhat inelastic, although not nearly so inelastic as that for raisins. ${ }^{16}$ The demand for fresh-Muscat grapes has been rather elastic.

The demand for table grapes does not change so much during the season as the demand for juice grapes, which apparently depends to a large extent upon temperatures favorable to the making of good wine. The bulk of sales of juice grapes, both black and white, in eastern markets has generally occurred during the month of October after mean temperatures of $50^{\circ}$ to $60^{\circ} \mathrm{F}$ have prevailed for a week or ten days. In years in which black-juice grapes and Muscats arrived in eastern markets in considerable volume a week or two before proper temperatures prevailed and active buying began, prices started at a lower level and averaged less for the whole season than in years with comparable total shipments in which substantial arrivals were delayed until active demand for juice grapes prevailed.

The uses for the bulk of table and juice varieties are so dissimilar that shipments of juice grapes were found to have no measurable effect on table-grape prices, and apparently table grapes have little influence on juice-grape prices, except insofar as any considerable tonnage of a table variety like Malagas are diverted into juice-grape channels. However, shipments of eastern labrusca grapes, the majority of which are probably used for table purposes, were found to affect the price of California table grapes to a minor extent.

Though there can be no doubt that quality has a substantial effect upon the eastern price of California grapes, lack of appropriate data have unfortunately precluded statistical measurement of its influence.

Because Muscat grapes are mostly utilized for wine-making by eastern buyers, there have been very evident and significant similarities in changes in the demand for black-juice grapes in recent years. Fresh Muscats have been extensively used in the East for blending with black-juice varieties and therefore these two classes of grapes appear to have both a complementary and a competitive relation to one another. Apparently there is a tendency to increase the proportion of whichever class of juice grapes is relatively the cheaper. Owing to the large increase in black-juice shipments, they have been relatively cheaper than Muscats, and apparently, therefore, a larger proportion of blends have been made from black-juice grapes in recent years. Partly as a result of variations in blending due to changes in

16 See accompanying paper: Shear, S. W., and R. M. Howe. Factors affecting California raisin sales and prices, 1922-1929. Hilgardia 6:73-100. 1931. 
relative prices, consumer annual outlays for juice stock have remained fairly uniform during the past nine years.

Fresh Muscat shipments, and hence prices, naturally are influenced by prevailing prices and expected advances for Muscat raisins at shipping time. As a result, in recent years in which prevailing prices and expected advances for raisins have been small compared with expected or prevailing returns from fresh shipments, the freshMuscat movement has usually been relatively large. On the other hand, when the raisin-price outlook appeared favorable, fresh-Muscat shipments have normally been curtailed and more dried for raisins.

\section{ACKNOWLEDGMENTS}

Grateful acknowledgement is expressed to Professor H. R. Tolley, Director of the Giannini Foundation, under whose guidance this study was made. Others who have generously assisted the authors are Dr. Holbrook Working, and Dr. Alonzo E. Taylor of the Food Research Institute, Stanford University; Mr. E. W. Stillwell of the Grape Control Board; Mr. W. F. Cox of the United States Department of Agriculture Bureau of Agricultural Economics; and Mr. Earl F. French of the New York Food Marketing Research Council.

\section{LITERATURE CITED IN TABLES}

1 Shear, S. W., and H. F. Gould.

1927 (June). Economic status of the grape industry. California Agr. Exp. Sta. Bul. 429:1-126.

2 Stillwell, E. W., and W. F. Cox.

1928 (August). Marketing California grapes. U. S. Dept. Agr. Cir. 44:1-153.

3 Cox, W. F.

1929. Statistics of California grape distribution for 1928. U. S. Dept. Agr.

Bur. Agr. Econ., California Vineyardists Association, Associated

California Fruit Industries and California State Division of Markets cooperating, mimeo. issued by California Division of

4 Cox, W. F. Markets, about 30 pages, not numbered.

1930. Statisties of California grape distribution for 1929. U. S. Dept. Agr. Bur. Agr. Econ., California Vineyardists Association, Associated California Fruit Industries and California State Division of Markets cooperating, mimeo. about 50 pages, not numbered. 
5 United States Department of Agriculture Bureau of Agricultural EConomics.

1925. Carload shipments of fruits and melons from stations in the United States for the calendar years 1920, 1921, 1.922, and 1923. U. S. Dept. Agr. Statis. Bul. 8:1-78.

6 U. S. Department of Agriculture, Bureau of Agricultural Economics.

1928. Car-lot shipments and unloads of important fruits and vegetables for the calendar years 1924-1926. U. S. Dept. Agr. Statis. Bul. 23:1-145.

7 Cox, W. F.

1929 (Aug. 5-Nov. 12). Market news reports on grapes. U. S. Dept. Agr. Bur. Agr. Econ. Mimeo. in Fresno daily during the greater part of the marketing season.

8 Schultz, C. E.

1927 (June). Marketing California grapes, summary of 1926. Mimeo. U. S. Dept. Agr. Bur. Agr. Econ. 103 p.

9 Willson, H. F., and J. M. Foote.

1929 (August). Marketing California grapes, summary of 1928 season. Mimeo. U. S. Dept. Agr. Bur. Agr. Econ. 103 p.

10 GOOGE, W. D.

1930 (August). Marketing California grapes, summary of 1929 season. Mimeo. U. S. Dept. Agr. Bur. Agr. Econ. 60 p.

11 Ezekiel, Mordecai.

1928 (February). Statistical analyses and the "laws" of price. Quar. Jour. Econ. 42:199-227.

12 Schultz, C. E. and C. J. Hansen.

1925 (July). Summary of California grapes, season 1924. Mimeo. U. S. Dept. Agr. Bur. Agr. Eeon. 76 p. 